\title{
Potential of using chemical enhanced oil recovery in the White Tiger field, offshore Vietnam
}

- Nguyen Phu Thinh

- Do Quang Khanh

- Hoang Trong Quang

University of Technology, VNU-HCM - doquangkhanh@yahoo.com

- Nguyen Viet Khoi Nguyen

PetroVietnam University

(Manuscript Received on August 19 $9^{\text {th }}, 2014$; Manuscript Revised November 11 $1^{\text {th }}, 2014$ )

\section{ABSTRACT:}

With growing global energy demand and depleting reserves, enhanced oil recovery (EOR) from existing or brown fields has become more and more necessary and important. Among the various enhanced oil recovery methods, chemical $E O R$ has drawn increasing interest from many petroleum companies. In this paper, the popular EOR methods are introduced briefly. Next, we also consider the EOR processes of chemical flooding and the screening criteria for chemical EOR processes in detail. Finally, based on the data of the White Tiger (Bach Ho) field, we evaluate and predict the potential of using chemical EOR at the main different petroleum reservoirs from the Miocene, Oligocene to fractured basement formations.

Keywords: Enhanced Oil Recovery (EOR), Chemical EOR, White Tiger (Bach Ho) field.

\section{INTRODUCTION}

Nowadays, with the development of the petroleum industry, EOR plays an important role for almost existing oil fields. Especially, EOR has become more and more necessary and effective for brown or mature field.

The term EOR is oil recovery by injection of special fluids, such as gases, chemicals, thermal energy or microbial into the reservoir. Depending on the producing life of a reservoir, oil recovery can be classified three phases: primary, secondary, and tertiary. EOR process is not only restricted to a particular phase, but it is also related in the producing life of the reservoir.

EOR refers to any reservoir process to change the existing rock/oil/brine interactions in the reservoir. There are a lot of EOR methods (James J. Sheng, 2011), such as:
- Thermal recovery: steam, in situ combustion, hot water, etc.

- Solvent: hydrocarbon miscible, $\mathrm{CO}_{2}, \mathrm{CO}_{2}$ miscible, nitrogen, flue gas, etc.

- Chemical flooding: alkaline, surfactant, micellar polymer, polymer, etc.

\section{- Microbial.}

Among these above methods, chemical EOR has been used from many oil companies. Especially, it has been more applicable and effective for brown/mature fields at offshore environment, such as the White Tiger field, Vietnam. Therefore, in the paper the term EOR and popular EOR methods are presented briefly. Next, we concentrate on the EOR process of chemical flooding and consider in detail the screening criteria for chemical EOR process. Finally, based on the data available of the White Tiger field, we will evaluate the potential of using chemical EOR at the main petroleum reservoirs from the Miocene, Oligocene to fracture basement formations. 


\section{OVERVIEW OF THE WHITE TIGER FIELD}

The White Tiger (Bach Ho) field, the largest one is located in the centre of the Cuu Long basin, offshore Southern Vietnam (Figure 1). It is near VungTau City about $145 \mathrm{~km}$ and HoChiMinh City about $225 \mathrm{~km}$.

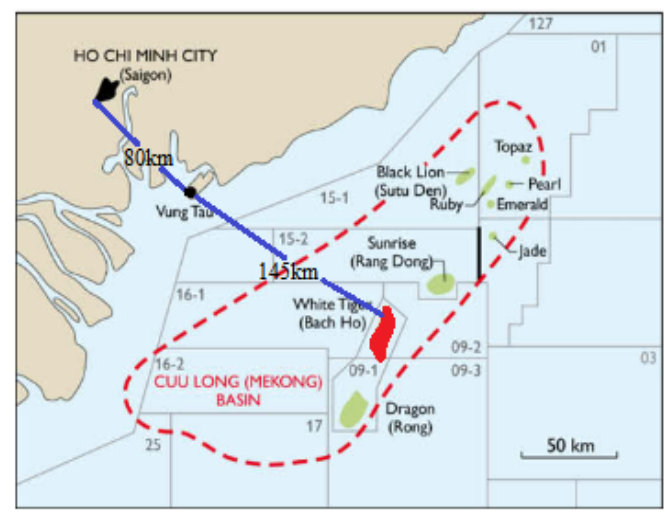

Figure 1. Location map of the study area

It is an unusual buried hill reservoir with the fractured reservoir matrix largely made up of unaltered acid igneous lithologies. A major NE-SW late Oligocene reverse fault system cross-cuts the field, with about $2000 \mathrm{~m}$ of lateral displacement in the highly productive Central Block. The associated fracture meshwork greatly enhances reservoir quality (Cuong and Warren, 2009). The White Tiger basement is made of three zones: North, Central and South blocks bounded and separated by a NE-SW fault system (Figure 2). The reverse fault to NW of the Central block locally has a lateral displacement (up to $2000 \mathrm{~m}$ ) in the NW flank of this field. The reverse fault dies out along and passes into a linked normal fault to both NE and SW. This relationship implies that the reserve-faulted margin of the Central block is an inverted portion of a pre-existing normal fault. In areas along the reverse fault, particularly in the Central block, fracture intensity is very high. The associated fracture meshwork greatly enhances reservoir quality. Most of the production wells in these areas maybe have high production rates (Cuong and Warren, 2009; Khanh et al, 2013).

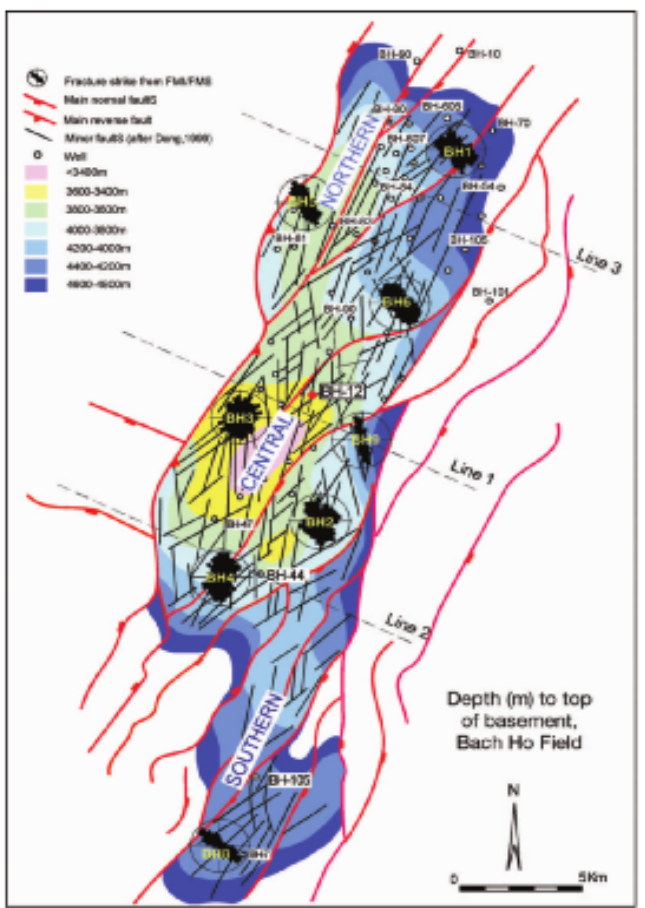

\section{Trang 118}


Figure 2. Main fault and fracture system in the White Tiger field (After Cuong and Warren, 2009)

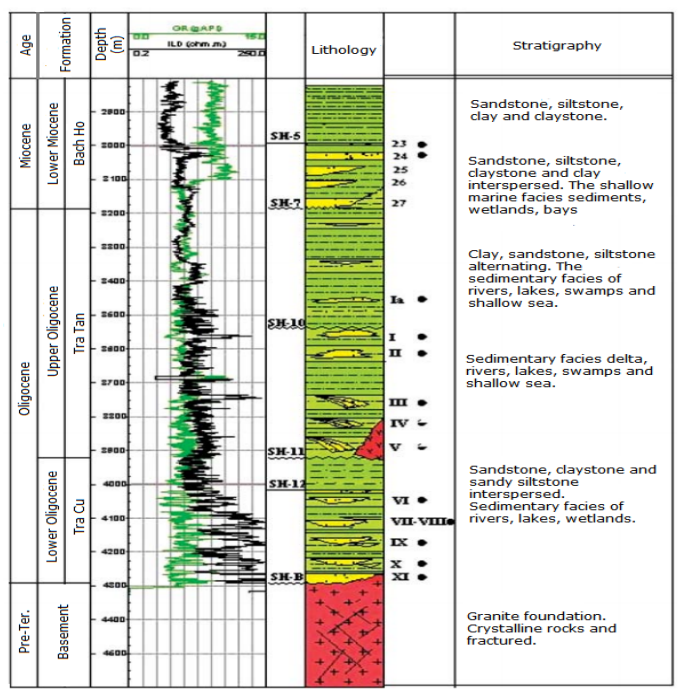

Figure 3. Stratigraphic section of the White Tiger field

The geologic age of the White Tiger field ranges from Late Mesozoic to Quaternary (Dien et al, 1998). The sedimentary succession at the White Tiger field comprises Eocene, Oligocene and lower Miocene deposits (Figure 3).

Sandstones in the lower Oligocene and lower Miocene successions are possible secondary reservoir targets at the White Tiger field. Late Oligocene lacustrine and lower Miocene marine shales constitute regional seals. Oils throughout the Cuu Long Basin are sourced from lacustrine muds. Source rocks in the White Tiger field are present in the Eocene and Oligocene intervals, with the upper Oligocene being the most prolific. The current geothermal gradient at the White Tiger field increases with formation age. Communica- tion between fractured basement and onlapping sandstones is not seen in current production and pressure data.

In 1975, Mobil Oil Company drilled the discovery well for the White Tiger field. However, this field was not developed until the mid-1980s, it has developed and managed by Vietsovpetro. Until now the producing life of the White Tiger filed is more than twenty five years. Moreover, the field's average daily production is declining. This rate of decline is somewhat higher than that predicted by Vietsovpetro, which envisaged an annual decline of about 20,000 b/d for the period 20102014 , but it can perhaps be expected in a field producing from an open fracture system with little matrix storage (Cuong and Warren, 2009). Therefore, the need of using
EOR process in this mature field should be more and more necessary and important for energy strategy.

\section{CHEMICAL EOR AND SCREENING CRITERIA}

Until now, although the cost of chemicals is not cheap, the chemical EOR processes are more and more applicable and effective. In general, chemical EOR processes include alkaline (A), surfactant (S), polymer (P) and any combination of these processes.

Main chemical EOR processes can be classified into Polymer Flooding, Surfactant Flooding, Alkaline Flooding, Alkaline-Polymer Flooding, AlkalineSurfactant Flooding, Surfactant-Polymer Flooding and Alkaline-Surfactant-Polymer Flood- ing. (James J. Sheng, 2011).

Polymer Flooding methods used synthetic polymers, such as hydrolyzed polyacryl-amide (HPAM) and biopolymers, such as xanthan gum.

Surfactant Flooding methods may be classified according to the ionic nature of the surfactants such as anionic, cationic, etc. Anionic may be most widely used in chemical EOR processes because they exhibit relatively low adsorption on sandstone rocks whose surface charge is negative. Besides, a mixture of anionic and nonionic is used to increase the tolerance to salinity. Cationic can be used in carbonate rocks to change wettability from oil-wet to water-wet. 
Alkaline Flooding methods used for in situ formation of surfactants such as sodium hydroxide $(\mathrm{NaOH})$; sodium orthosilicate $\left(\mathrm{Na}_{4} \mathrm{SiO}_{4}\right)$; sodium metasilicate (water glass or liquid glass, $\mathrm{Na}_{2} \mathrm{SiO}_{3}$ ); sodium bicarbonate $\left(\mathrm{NaHCO}_{3}\right)$, etc. Alkaline consumption in the field is higher than that in the laboratory but oil recovery factor in the field is generally lower than that in the laboratory. Therefore, alkaline flooding is combined with other methods, such as surfactant, polymer, etc. will be applied.

Alkaline-Polymer (A/P) Flooding methods are the combination of alkaline and polymer that alkaline consumption in an alkaline-polymer systems is lower than in the alkaline solution. Besides, polymer makes the alkaline-polymer solution more viscous to improve sweep efficiency.

Alkaline-Surfactant (A/S) Flooding methods may reduce surfactant adsorption and in situ soap generation, synergy between in situ generated soap and injected surfactant.

Surfactant-Polymer (S/P) Flooding methods are the injected surfactant and polymer in the same slug. Sometimes, polymers are injected before or behind surfactant depend on compatibility.

Alkaline-Surfactant-Polymer (A/S/P) Flood- ing methods are the combination of alkaline flooding, surfactant flooding, and polymer flooding. This was the most efficient approach, demonstrating the synergy of alkali, surfactant, and polymer floods.

The following figure will illustrated the main operation principles of the chemical EOR process (Figure 4). This method requires a preflush to condition the reservoir, the injection of a micellar fluid for releasing oil, followed by a polymer solution for mobility control to minimize channeling, and a driving fluid (water) to move the chemicals and resulting oil bank to production wells.

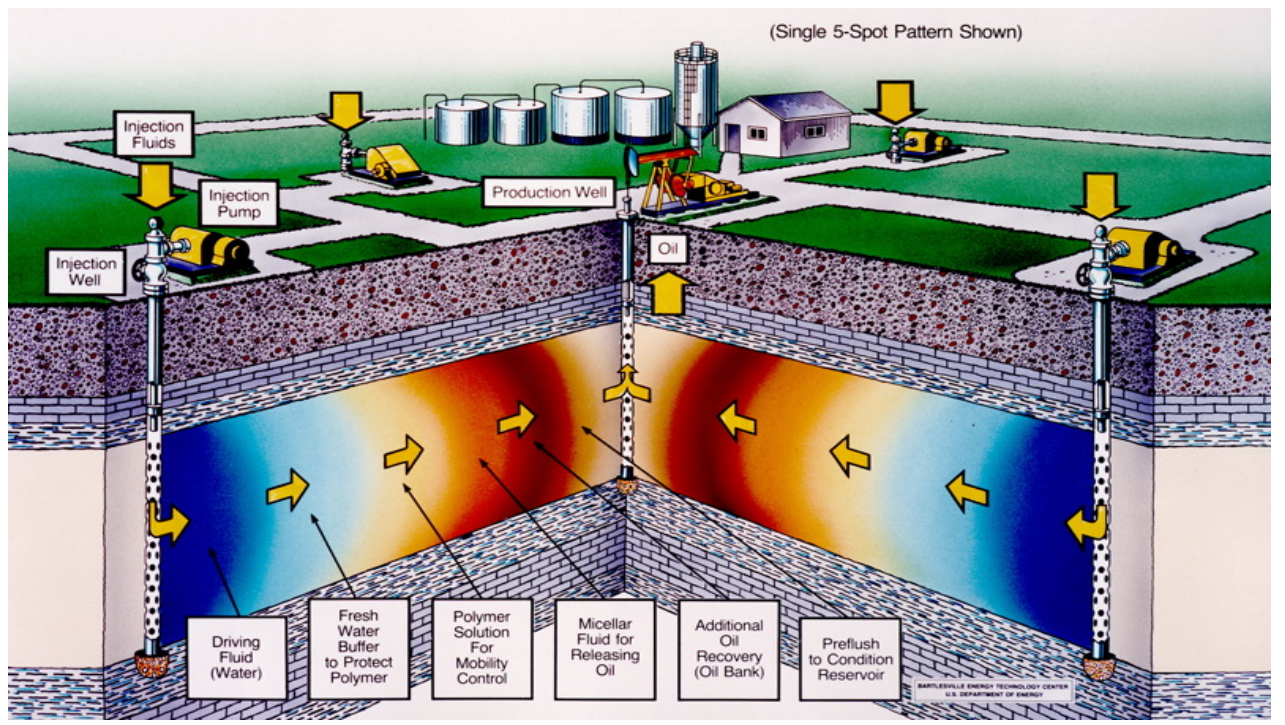

Figure 4. Chemical Flooding (Micellar - Polymer)

Actually, there are many parameters affecting chemical EOR processes. However, the most critical parameters should be reservoir temperature formation salinity and divalent contents, clay contents, and oil viscosity (James J. Sheng, 2011). These parameters may be as:

- Formation: Until now, almost all chemical EOR applications have been in sandstone reservoirs over the world. One reason for fewer applications in carbonate reservoirs is that anionic surfactants have high adsorption in carbonates. Moreover, anhydrite often exists in carbonates, which causes precipitation and high alkaline consumption. Clays also cause high surfactant and polymer adsorption and high alkaline consumption. Therefore, clay contents must be low for a chemical EOR application to be effective.

\section{Trang $\mathbf{D O}$}


- Formation Water Salinity and Divalents:

Formation water salinity and divalents are critical to chemical EOR processes for both surfactants and polymers. Although chemical suppliers claim their products can be tolerant to high salinity, most of the chemical EOR processes have been applied in low salinity reservoirs. The criterion discussed is 50,000 ppm salinity and 1000 ppm hardness. This 1000 ppm hardness is probably too high or needs extra chelating agents. It must be emphasized that the salinity and divalent limits depend on the type of polymer used.

- Reservoir Temperature: The reservoir temperature should be lower than $93^{\circ} \mathrm{C}$ for $\mathrm{A} / \mathrm{S} / \mathrm{P}$ projects, but the average temperature for the actual $\mathrm{A} / \mathrm{S}$ field projects they reported was $27^{\circ} \mathrm{C}$. The average temperature for their reviewed 171 polymer projects was $49^{\circ} \mathrm{C}$ for the projects (Taber et al., 1997). However, some chemical suppliers state that polymer can be applied up to $120^{\circ} \mathrm{C}$. The criterion used is $70^{\circ} \mathrm{C}$, which is on the lower side (James J. Sheng, 2011). Sorbie's
(1991) upper limit for polymer is $80^{\circ} \mathrm{C}$, and the maximum is $95^{\circ} \mathrm{C}$.

- $\quad$ Formation Permeability: High permeability is favorable to chemical flooding, and it is critical to polymer flooding. Low-permeability formation will have injectivity and excess retention problems. Interestingly, Taber et al. (1997) showed that although the criterion for chemical projects is greater than $10 \mathrm{md}$, the average permeability in their reviewed actual projects were $450 \mathrm{md}$ for $\mathrm{A} / \mathrm{S}$ and $800 \mathrm{md}$ for polymer flooding.

- Oil Composition and Oil Viscosity: Oil composition is very important to alkaline - surfactant flooding because different surfactants must be selected for different oils, but it is not critical to polymer flooding. According to Taber et al. (1997), oil viscosity should be less than $35 \mathrm{mPa} \cdot \mathrm{s}$. for $\mathrm{A} / \mathrm{S}$ projects. For polymer flooding, oil viscosity could be 10 to 150 $\mathrm{mPa} \cdot \mathrm{s}$. Sorbie (1991) defined $30 \mathrm{mPa} \cdot \mathrm{s}$ as the upper limit of oil viscosity for polymer flooding, and $70 \mathrm{mPa} \cdot \mathrm{s}$ as the maximum.

Table 1. Summary of Screening Criteria for EOR methods

\begin{tabular}{|c|c|c|c|c|c|c|c|c|c|c|}
\hline & \multirow[b]{2}{*}{ EOR Method } & \multicolumn{3}{|c|}{ Oil Properties } & \multicolumn{6}{|c|}{ Reservoir Characteristics } \\
\hline & & $\begin{array}{l}\text { Gravity } \\
{ }^{\circ} \mathrm{API}\end{array}$ & Viscosity (cp) & Composition & $\begin{array}{c}\text { Oil } \\
\text { Saturation } \\
(\% \mathrm{PV})\end{array}$ & $\begin{array}{l}\text { Formation } \\
\text { Type }\end{array}$ & $\begin{array}{c}\text { Net } \\
\text { Thickness } \\
\text { (ft) }\end{array}$ & $\begin{array}{l}\text { Average } \\
\text { Permeability } \\
\text { (md) }\end{array}$ & $\begin{array}{l}\text { Depth } \\
\text { (ft) }\end{array}$ & $\begin{array}{c}\text { Temperature } \\
\left({ }^{\circ} \mathrm{F}\right)\end{array}$ \\
\hline \multirow{3}{*}{$\begin{array}{c}\text { Gas } \\
\text { Injection } \\
\text { methods } \\
\text { (miscible) }\end{array}$} & $\begin{array}{l}\text { Nitrogen } \\
\text { (\& Flue Gas) }\end{array}$ & $>35^{\uparrow} \underline{48}^{1}$ & $<0.4^{*} \underline{0.2}$ & $\begin{array}{l}\text { High \% of } C_{1}- \\
C_{7}\end{array}$ & $>40^{4} \underline{75}$ & $\begin{array}{l}\text { Sandstone } \\
\text { or } \\
\text { Carbonate }\end{array}$ & $\begin{array}{l}\text { Thin } \\
\text { unless } \\
\text { dipping }\end{array}$ & N.C. ${ }^{2}$ & $>6,000$ & N.C. \\
\hline & Hydrocarbon & $>23^{\uparrow} \underline{41}$ & $<3^{*} \underline{0.5}$ & $\begin{array}{l}\text { High \% of } \mathrm{C}_{2}- \\
\mathrm{C}_{7}\end{array}$ & $>30^{\uparrow} \underline{80}$ & $\begin{array}{l}\text { Sandstone } \\
\text { or } \\
\text { Carbonate }\end{array}$ & $\begin{array}{l}\text { Thin } \\
\text { unless } \\
\text { dipping }\end{array}$ & N.C. & $>4,000$ & N.C. \\
\hline & Carbon Dioxide & $>22^{\uparrow} \underline{36}$ & $<10^{\star} \underline{1.5}$ & $\begin{array}{l}\text { High \% of } \mathrm{C}_{5}- \\
\mathrm{C}_{12}\end{array}$ & $>20^{\uparrow} \underline{55}$ & $\begin{array}{l}\text { Sandstone } \\
\text { or } \\
\text { Carbonate }\end{array}$ & $\begin{array}{l}\text { (Wide } \\
\text { range) }\end{array}$ & N.C. & $>2,500$ & N.C. \\
\hline \multirow[t]{2}{*}{ Chemical } & $\begin{array}{l}\text { Micellar/- } \\
\text { Polymer, } \\
\text { Alkaline/- } \\
\text { Polymer } \\
\text { (ASP), and } \\
\text { Alkaline } \\
\text { Flooding }\end{array}$ & $>20^{\uparrow} \underline{35}$ & $<35^{+} \underline{13}$ & \begin{tabular}{|l|} 
Light, \\
intermediate, \\
Some organic \\
acids \\
for alkaline flood
\end{tabular} & $>35^{4} \underline{53}$ & $\begin{array}{l}\text { Sandstone } \\
\text { preferred }\end{array}$ & N.C. & $>10^{\uparrow} \underline{450}$ & $\begin{array}{l}<9,000 \\
+\underline{3,250} \\
\underline{3}\end{array}$ & $<20{ }^{\star} \underline{80}$ \\
\hline & $\begin{array}{l}\text { Polymer } \\
\text { Flooding }\end{array}$ & $>15-<40$ & $<150,>10$ & N.C. & $>70^{\uparrow} \underline{80}$ & $\begin{array}{l}\text { Sandstone } \\
\text { preferred }\end{array}$ & N.C. & $>10^{\uparrow} \underline{800}$ & $<9,000$ & $<200^{\star} \underline{140}$ \\
\hline \multirow{2}{*}{ Thermal } & Combustion & $>10^{\uparrow} \underline{16}$ & $\begin{array}{r}<5,000 \\
+\underline{1200} \\
\end{array}$ & $\begin{array}{l}\text { Some asphaltic } \\
\text { components }\end{array}$ & $>50^{\uparrow} \underline{72}$ & $\begin{array}{l}\text { High porosity } \\
\text { sand/ } \\
\text { sandstone }\end{array}$ & $>10$ & $>50$ & $\begin{array}{l}<11,500 \\
+3,500\end{array}$ & $>100^{\uparrow} \underline{135}$ \\
\hline & Steam & $>15-\underline{13.5}$ & $\begin{array}{l}<200,000 \\
+\underline{4700}\end{array}$ & N.C. & $>40^{\dagger} \underline{66}$ & $\begin{array}{l}\text { High porosity } \\
\text { sand/ } \\
\text { sandstone }\end{array}$ & $>20$ & $>200$ & $\begin{array}{l}<4,500 \\
+1,500\end{array}$ & N.C. \\
\hline
\end{tabular}


1. Underline values represent the approximate mean or average for current field projects. ${ }^{\dagger}$ indicates higher value of parameter is better. 2. N.C. $=$ not critical

The information provided here can serve as a reference for potential projects. Among the parameters discussed, reservoir temperature and water salinity are the most critical parameters. However, nowadays as chemical products are improved significantly, the criteria may be changed. From the current chemical EOR technology, extensive laboratory measurements still are needed for every project. Simulation work is also needed to analyze laboratory data and upscale to a field model for potential prediction. Actually, until now the chemical EOR application in reservoir with the high temperature and high salinity is still a challenging task.

Moreover, the application of EOR processes can be evaluated the screening criteria for EOR methods (Don W. Green and G. Paul Willhite, 1998). It is summarized in the following table (Table 1). In the table, the affecting elements to EOR methods can be two main groups: oil properties and reservoir characteristics.

\section{ANALYSIS OF POTENTIAL USING CHEMICAL EOR PROCESS IN THE WHITE TIGER FIELD, VIETNAM}

Based on data available of the White Tiger field (Vietsovpetro, 2013) and screening criteria for EOR (James J. Sheng, 2011), we conduct to evaluate and predict the potential using chemical EOR processes at the petroleum reservoirs from the Miocene, Oligocene to fracture basement formations of the White Tiger field, Vietnam.

\subsection{At petroleum reservoirs in the Miocene formation}

The Miocene formation of the White Tiger field holds $47 \mathrm{MM} \mathrm{m} 3$ of original oil-in-place (OOIP) and has been under water injection since 1986, with an estimated final recovery of $26.5 \%$. Data available by Vietsovpetro indicate the following reservoir conditions for the Lower Miocene of the White Tiger field as:

- $\quad$ Rock type: sandstone

- $\quad$ Reservoir pay thickness (ft): 120

- $\quad$ Depth (ft): 9,000 - 10,500
- $\quad$ Permeability range (mD): 170 (avg.), up to 1,000

- Porosity (\%): 20

- Temperature: $230^{\circ} \mathrm{F}\left(110^{\circ} \mathrm{C}\right)$

- $\quad$ Oil Gravity ( $\left.{ }^{\circ} \mathrm{API}\right): 40$

- $\quad$ Oil viscosity at reservoir temperature (cP): 11.7

- $\quad$ Injection water salinity (g/L TDS): 36 (sea water)

A high-level screening of EOR methods indicates that both gas and chemical processes could be applied, with a higher potential for chemical injection:

- Gas injection (including Water-AlternateGas), although applicable, would have an efficiency limited by the difficulty of reaching miscibility in reservoir conditions.

- Injection of a combination of polymer and surfactants could improve the sweep efficiency of the waterflood and recover trapped oil beyond. It would also make use of water injection facilities, although additional storage, preparation and mixing would be needed. Chemical injection also presents a higher feasibility risk, and requires a higher degree of customization.

From the screening criteria, we see that many characteristics of this formation are favorable to using chemical EOR, such as (sandstone lithology, high residual oil in place, good permeability and moderate oil viscosity. However, the combination of high temperature $230^{\circ} \mathrm{F}\left(110^{\circ} \mathrm{C}\right)$ and high injection water salinity (sea water) creates strong challenges both for products stability and adsorption, and places the Miocene formation outside of the traditional scope of applicability of chemical EOR methods.

Recent technological developments have enlarged this traditional scope of applicability towards temperatures around $230^{\circ} \mathrm{F}\left(120^{\circ} \mathrm{C}\right)$, salinities ranging from a few $\mathrm{g} / \mathrm{L}$ up to $150-200 \mathrm{~g} / \mathrm{L}$ TDS (total dissolved solids), and water hardness up to several times that of sea water through. These include notably: surfactant and polymers stable at higher temperature/higher

\section{Trang 22}


salinity conditions; processes supporting applications in hard brine context though the use of adsorption inhibitors.

Therefore, a surfactant - polymer process can be envisaged to mobilize a substantial part of the residual oil in place in the petroleum reservoirs at the Miocene formation. Moreover, polymer process could also be considered, although the low oil viscosity is likely to limit its attractiveness.

\subsection{At petroleum reservoirs in the Oligocene formation}

Data available by Vietsovpetro indicate the following reservoir conditions for the Oligocene formation of the White Tiger field as:

- $\quad$ Rock type: claystone, siltstone, sandstone

- $\quad$ Reservoir pay thickness (ft): 358

- $\quad$ Depth (ft): 9,000 - 11,500

- $\quad$ Porosity (\%): 10.5 - 14.45

- $\quad$ Fracture permeability range (mD): 103 - 286 $\mathrm{mD}$ estimated

- $\quad$ Temperature: $255^{\circ} \mathrm{F}\left(124^{\circ} \mathrm{C}\right)$

- $\quad$ Oil Gravity ( $\left.{ }^{\circ} \mathrm{API}\right): 40$

- Oil viscosity at reservoir temperature $(\mathrm{cP})$ :

0.244

- Injection water salinity (g/L TDS): 36 (sea water)

Comparing to the Miocene formation, the petroleum reservoir in the Oligocene formation also is favorable to use EOR methods such as $\mathrm{CO}_{2}$ injection or surfactant flooding.

$\mathrm{CO}_{2}$ injection may be used by wide range ability and conformity of many characteristics but this method is limited by the difficulty of reaching $\mathrm{CO}_{2}$ sources.

Surfactant flooding still may be used for EOR processes. However, we must consider using chemical EOR carefully because this formation is more complex and thicker, deeper than Miocence formation. Therefore, a combination of surfactants could improve the stability in high temperatures, hardness and salinity to increase oil recovery in the Oligocene formation. Besides, the surfactants with critical micelle concentration must be low; means that only uses a small amount of surfactants may be effective for EOR processes.

\subsection{At petroleum reservoirs in the fractured basement formation}

Most oil production at petroleum reservoirs of the White Tiger field (the largest field in the Cuu Long basin) have been recovered from fractured basement reservoirs. The oil bearing basement rocks undergone in three stages: pre-rift (before middle Eocene), rifting stage (middle Eocene-early Miocene) and post-rift (middle Miocene to present day). Oil is accumulated in fractures, pores and vuggy, which had been formed in hydrothermal alteration and tectonic processes. Secondary porosity and permeability are considered as efficient storage.

The top of fractured reservoirs is positioned at a depth of about $10,100 \mathrm{ft}$, liquids production is less than 15,500 $\mathrm{ft}$, deepest producing interval at about $16,710 \mathrm{ft}$.

Data available by Vietsovpetro indicate the following reservoir conditions in the fractured basement of the White Tiger field as following:

- $\quad$ Rock type: fractured basement

- $\quad$ Reservoir pay thickness (ft): 1500

- $\quad$ Depth (ft): 16,000

- $\quad$ Fracture permeability range (mD): $1500 \mathrm{mD}$ estimated

- $\quad$ Temperature: $284^{\circ} \mathrm{F}\left(140^{\circ} \mathrm{C}\right)$

- $\quad$ Oil Gravity $\left({ }^{\circ} \mathrm{API}\right): 40$

- $\quad$ Oil viscosity at reservoir temperature $(\mathrm{cP})$ : 1.3

- Injection water salinity (g/L TDS): 36 (sea water)

Fractured basement reservoirs may be considered as unconventional reservoirs over the world. Hence, recovery optimization by EOR or drilling development requires fine and detailed reservoir studies to success. Refer to the screening criteria of EOR methods with data available of petroleum reservoirs at the fractured basement formation, gas injection methods from associated gas or $\mathrm{CO}_{2}$ would be most favorable to this formation.

Besides, surfactant flooding is also an option may be used if new chemicals are developed for high temperature. Considering complex fractures network of basement and unfavorable mobility ratio using gas injection, foam gas injection could be a solution to improve gas mobility. However, reservoir temperature rises to about $284^{\circ} \mathrm{F}\left(140^{\circ} \mathrm{C}\right)$. This is very high to the limit temperature about $248^{\circ} \mathrm{F}\left(120^{\circ} \mathrm{C}\right)$ of current chemicals. So, at the present time, both surfactant flooding and foam injection methods must not be 
selected for EOR processes in the reservoir of the fractured basement.

\section{CONCLUSIONS}

From the above studies, we conclude the following conclusions:

- $\quad$ The EOR processes are very necessary and important for brown or mature fields, such as the White Tiger Field, Vietnam.

- $\quad$ The most favorable chemical EOR methods for petroleum reservoirs in the White Tiger field may be: the surfactant - polymer flooding envisaged in the Miocene formation; the combination of surfactants stable in temperatures, hardness and high salinity seawater to increase oil recovery in the Oligocene formation; and gas injection method in the fractured basement formation.

- $\quad$ Although the chemical EOR processes require no small cost, but its ability and effectiveness are large for the White Tiger Field. However, reservoir temperature, water salinity and depth are the most critical parameters when using chemical EOR processes. Therefore, we should choose and supplement chemicals restricting effects of high temperature, water salinity for the chemical EOR processes at deeper petroleum reservoirs.

\section{Khả năng ứng dụng thu hồi dầu tăng cường hoá học tại mỏ Bạch Hổ, ngoài khơi Việt Nam}

- Nguyễn Phú Thịnh

- Đỗ Quang Khánh

- Hoàng Trọng Quang

Trường Đại học Bách khoa, ĐHQG-HCM

- Nguyễn Viết Khôi Nguyên

Trường Đại học Dầu khí

\section{TÓM TÁ́T:}

Với nhu cầu năng lượng toàn cầu gia tăng và trữ lượng cạn kiệt, công tác thu hồi dầu tăng cường (EOR) tại các mỏ đang khai thác ngày càng trở nên cần thiết và quan trọng hơn. Trong số các phương pháp thu hồi dầu tăng cường khác nhau, thu hồi dầu tăng cường hoá học đã thu hút được sự quan tâm ngày càng tăng từ nhiều công ty dầu khí. Trong bài báo này, các phương pháp thu hồi chúng tôi cũng xem xét các quá trình thu hồi dầu tăng cường hoá học và các tiêu chí sàng lọc các quá trình đó một cách chi tiết. Cuối cùng, dựa trên dữ liệu của mỏ Bạch Hổ (White Tiger), nhóm tác giả đánh giá và dụ̣ đoán tiềm năng của việc sử dụng thu hồi dầu tăng cường hóa học tại các via dầu khí chính từ thành hệ Miocene, Oligocene và tầng móng nứt nẻ. dầu tăng cường phổ biến được giới thiệu. Sau đó,

Từ khóa: Thu hồi dầu tăng cường (EOR), Thu hồi dầu tăng cường hoá học, Mỏ Bạch Hổ (White Tiger).

\section{Trang D4}




\section{TÀI LIỆU THAM KHẢO}

[1]. Cuong, T. X. and Warren, J. K. (2009). Bach Ho field, a fractured granitic basement reservoir, Cuu Long basin, offshore SE Vietnam: A "buried-hill" play, Journal of Petroleum Geology, Vol. 32(2), 129-156.

[2]. Dien, P. T., Tai, P. S., Dzung, L. V., Tiem, P. V. and Nhuan, D. V. 1998. Late-Mesozoic and Early Cenozoic events and petroleum system of the Cuu Long Basin. PetroVietnam Review, 1-1998, 4-23.

[3]. Don W. Green and G. Paul Willhite (1998). Enhanced Oil Recovery, SPE Textbook Series Vol. 6.

[4]. James J. Sheng (2011). Modern Chemical Enhanced Oil Recovery, Theory and Practice.
[5]. Khanh, D. Q., An, B.T., Yang H. Y. (2013). Estimating present-day stress orientation from analysis of breakouts in the fractured basement formation at the White Tiger (Bach Ho) field, Cuu Long basin, offshore Southern Vietnam. Proceedings of the $13^{\text {th }}$ Conf. of Sci.\& Tech., HCMCUT, VN.

[6]. Sorbie, K.S. (1991), Polymer-Improved Oil Recovery, CRC Press.

[7]. Taber J. J et al. (1997), EOR Screening Criteria Revisited, SPE \#35385.

[8]. Vietsovpetro (2013), Reports of Workshop Presentations on EOR processes 